\title{
KEADILAN DALAM PERSPEKTIF FILSAFAT ILMU HUKUM
}

\author{
Inge Dwisvimiar \\ Universitas Sultan Ageng Tirtayasa \\ E-mail: ingedwi@yahoo.co.id
}

\begin{abstract}
The author in this paper tries to investigate and describe the perspective of J ustice in Legal Studies. Fairness in Legal Studies Philosophy attention to all aspects of terminology relating to justice and legal philosophy of science. Justice is the ideals and purposes of the law that reach from the philosophy of science perspective of the law by providing that justice is realized through law. By reviewing the opinion of Plato and Aristotle as the foundations of justice, Thomas Aquinas, who called for justice as well as John Rawls proportional equality with justice fairness the the basic values of justice are included in the study of philosophy of science philosophy of law will be answered by the legal science it self. The justice is not just there and read the text of legislation but also the legal justice in society. Both Article 16 paragraph (1) Law 4/2004 and Article 5 paragraph (1) Law 48/2009 states that justice shall be upheld in spite of no normative provisions and how thejudge alone buat also to explore and understand the values and sense of justice that exists in the community.
\end{abstract}

Key words: justice, legal studies, philosophy of science of law

\begin{abstract}
Abstrak
Penulis dalam tulisan ini mencoba untuk menyelidiki dan menggambarkan Keadilan dalam perspektif IImu Hukum. Keadilan dalam Filsafat IImu Hukum memperhatikan semua aspek berkenaan dengan terminologi keadilan dan filsafat ilmu hukum. Keadilan merupakan cita-cita dan tujuan hukum yang menjangkau wilayah filsafat ilmu hukum dengan memberikan perspektif bahwa keadilan diwujudkan melalui hukum. Dengan mengkaji pendapat dari Plato dan Aristoteles sebagai peletak dasar-dasar keadilan, Thomas Aquinas yang menyebut keadilan sebagai sesuatu kesamaan proporsional serta J ohn Rawls dengan keadilan fairness maka nilai-nilai dasar keadilan yang masuk dalam kajian filsafat ilmu hukum akan dijawab oleh filsafat ilmu hukum itu sendiri. Adapun keadilan tidak saja ada dan terbaca dalam teks perundang-undangan akan tetapi ada juga keadilan hukum dalam masyarakat. Baik pasal 16 ayat (1) UU 4/ 2004 dan pasal 5 ayat (1) UU 48/2009 menyatakan bahwa keadilan waj ib ditegakkan kendatipun tidak ada dalam ketentuan normatif serta bagaimana hakim juga dapat menggali dan memahami nilai-nilai dan rasa keadilan yang ada dalam masyarakat.
\end{abstract}

Kata kunci: keadilan, ilmu hukum, filsafat ilmu hukum.

\section{Pendahuluan}

Ukuran mengenai keadilan seringkali ditafsirkan berbeda-beda. Keadilan itu sendiri pun berdimensi banyak, dalam berbagai bidang, misalnya ekonomi, maupun hukum. Dewasa ini, berbicara mengenai keadilan merupakan hal yang senantiasa dijadikan topik utama dalam setiap penyelesaian masalah yang berhubungan dengan penegakan hukum. Banyaknya kasus hukum yang tidak terselesaikan karena ditarik ke masalah politik. Kebenaran hukum dan keadilan dimanipulasi dengan cara yang sistematik sehingga peradilan tidak menemu- kan keadaan yang sebenarnya. Kebijaksanaan pemerintah tidak mampu membawa hukum menjadi "panglima" dalam menentukan keadilan, sebab hukum dikebiri oleh sekelompok orang yang mampu membelinya atau orang yang memiliki kekuasaan yang lebih tinggi. ${ }^{1}$

Sebagai contoh dapat diilustrasikan dalam penerapan beberapa putusan pengadilan yang sering dianggap mematikan rasa keadilan

\footnotetext{
Muchsan, 1985, Hukum Tata Pemerintahan, Yogyakarta: Penerbit Liberty, hlm. 42. Bandingkan dengan M. Husni, "Moral dan Keadilan Sebagai Landasan Penegakan Hukum Yang Responsif", J urnal Equality Fakultas Hukum Universitas Sumatera Utara, Vol. 11 (1) Februari 2006, hlm. 1-7
} 
masyarakat. Misalnya dalam putusan bebas yang dijatuhkan oleh majelis hakim Pengadilan Negeri Jakarta Selatan beberapa waktu lalu, terhadap terdakwa dalam kasus korupsi Bank Mandiri yang dituntut oleh Jaksa 20 tahun penjara, mengundang berbagai pro dan kontra. ${ }^{2}$ Berkaitan dengan pengusutan pelanggaran HAM masa lalu melalui penegakan supremasi hukum, keadilan pun menjadi bagian yang tidak terpisahkan dari penegakan HAM. $^{3}$ Contoh lain dalam kasus BLBI, kepastian hukum dan keadilan dalam kebijakan hukum yang diambil pemerintah telah menimbulkan ketidakadilan bagi sebagian tersangka/terdakwa serta masyarakat luas, bahkan tampak diskriminatif, dan kasus-kasus lainnya.

Seperti diketahui istilah keadilan senantiasa dipertentangkan dengan istilah ketidakadilan. Dimana ada konsep keadilan maka disitu pun ada konsep ketidakadilan. Biasanya keduanya disandingkan dan dalam konteks kajian hukum ada banyak contoh ketidakadilan yang merupakan antithese dari keadilan dalam bidang hukum misalnya di Indonesia, seperti : ketidakadilan dalam kasus Poso, terhadap rakyat kecil, kasus Prita, ketidakadilan pemberitaan, ketidakadilan pembagian BLT, ketidakadilan gender dalam masyarakat daerah, ketidakadilan dalam pemecahan masalah hukum, dan sebagainya.

Bahkan Susanto membahas sesuatu yang tidak biasa dalam memaknai keadilan, yang terkait dengan substansi yang ada di dalamnya. Keadilan akan dibenturkan dengan keraguan dan ketidakadilan, bahwa sesungguhnya keadilan tidak akan berdaya tanpa ketidakadilan dan keraguan. ${ }^{4}$ Membahas konsep keadilan, menu-

\footnotetext{
M. Amin, "Kebenaran Hukum Vs Keadilan Masyarakat", tersedia di website http://www. Pa - Iubukpakam. net/ artikel/ 186-kebenaran-hukum-vs-keadilanmasyarakat.html, diakses pada tanggal 9 Oktober 2010.

3 Lihat Syamsiar Julia, "Pelanggaran HAM Dan Peranan Polri Dalam Penegakan Hukum di Indonesia", J urnal Equality Fakultas Hukum Universitas Sumatera Utara, Vol. 11 (2) Agustus 2006, hlm. 115-122; Bandingkan dengan Todung Mulya Lubis, "Menegakan Hak Asasi Manusia, Menggugat Diskriminasi", J urnal Hukum dan Pembangunan Fakultas Hukum Universitas Indonesia, Vol. 39 (1) J anuari-Maret 2009, hlm. 58-73

4 Anthon F. Susanto, "Keraguan dan Ketidakadilan Hukum (Sebuah Pembacaan Dekonstruktif)", Jurnal Keadilan Sosial, Edisi 1 tahun 2010, hlm. 23.
}

rutnya, yang kemudian akan dibenturkan dengan ketidakadilan dan keraguan, akan memasuki medan wilayah non sistematik, atau anti sistematik, bahkan hampir bersifat aphoristic, karena membicarakan keadilan, ketidakadilan, keraguan kita berdiri pada wilayah yang labil, goyah atau cair (melee). Oleh karena itulah, keadilan (hukum) dianggap plural dan plastik. ${ }^{5}$

Keadilan, dalam literatur sering diartikan sebagai suatu sikap dan karakter. Sikap dan karakter yang membuat orang melakukan perbuatan dan berharap atas keadilan adalah keadilan, sedangkan sikap dan karakter yang membuat orang bertindak dan berharap ketidakadilan adalah ketidakadilan. Secara umum dikatakan bahwa orang yang tidak adil adalah orang yang tidak patuh terhadap hukum (unlawful, lawless) dan orang yang tidak fair (unfair), maka orang yang adil adalah orang yang patuh terhadap hukum (law-abiding) dan fair. Karena tindakan memenuhi/mematuhi hukum adalah adil, maka semua tindakan pembuatan hukum oleh legislatif sesuai dengan aturan yang ada adalah adil. Tujuan pembuatan hukum adalah untuk mencapai kemajuan kebahagiaan masyarakat. Maka, semua tindakan yang cenderung untuk memproduksi dan mempertahankan kebaha-giaan masyarakat adalah adil.

Keadilan sebagai bagian dari nilai sosial memiliki makna yang amat luas, bahkan pada suatu titik bisa bertentangan dengan hukum sebagai salah satu tata nilai sosial. Suatu kejahatan yang dilakukan adalah suatu kesa-lahan. Namun apabila hal tersebut bukan merupakan keserakahan tidak bisa disebut menimbulkan ketidakadilan. Sebaliknya suatu tindakan yang bukan merupakan kejahatan dapat menimbulkan ketidakadilan.

Ukuran keadilan sebagaimana di singgung di atas sebenarnya menjangkau wilayah yang ideal atau berada dalam wilayah cita, dikarenakan berbicara masalah keadilan, berarti sudah dalam wilayah makna yang masuk dalam

\footnotetext{
5 Erlyn Indarti, “Demokrasi dan Kekerasan: Sebuah Tinjauan Filsafat Hukum", Aequitas Juris, Jurnal Fakultas Hukum Universitas Katolik Widya Mandira Kupang, Fakultas Hukum Universitas Katolik Widya Mandira, Vol. 2 (1), 2008, hlm. 33
} 
tataran filosofis yang perlu perenungan secara mendalam sampai hakikat yang paling dalam, bahkan Kelsen menekankan pada filsafat hukum Plato, bahwa keadilan didasarkan pada pengetahuan perihal sesuatu yang baik ${ }^{6}$. Pengetahuan akan hal yang baik secara fundamental merupakan persoalan di luar dunia. Hal tersebut dapat diperoleh dengan kebijaksanaan. ${ }^{7}$

J elas bahwa keadilan masuk ke dalam kajian ilmu-ilmu filsafat. Banyak filsafat yang mengharapkan inspirasi bagi pengetahuan keadilan. Kesemua itu termasuk filsafat-filsafat yang sangat berbeda dalam ruang dan waktu. Keadilan merupakan salah satu contoh materi atau forma yang menjadi objek filsafat. Dalam kajian filsafat, keadilan telah menjadi pokok pembicaraan serius sejak awal munculnya filsafat Yunani. Pembicaraan keadilan memiliki cakupan yang luas, mulai dari yang bersifat etik, filosofis, hukum, sampai pada keadilan sosial. Banyak orang yang berpikir bahwa bertindak adil dan tidak adil tergantung pada kekuatan dan kekuatan yang dimiliki, untuk menjadi adil cukup terlihat mudah, namun tentu saja tidak begitu halnya penerapannya dalam kehidupan manusia.

Keadilan menjadi bagian yang tidak terpisahkan dari tujuan hukum itu sendiri, di samping kepastian hukum dan kemanfaatan. Mensikapi adanya beberapa permasalahan (baca: kasus) hukum yang terjadi di negara Indonesia yang kemudian dituangkan dalam beberapa putusan hakim ${ }^{8}$ sehingga membawa pada satu pe-

6 W. Friedmann, 1990, Teori dan Filsafat Hukum, J akarta: PT. Rajawali Press, hlm. 118.

7 Filsafat, dalam satu pengertiannya diartikan sebagai suatu kebijaksanaan yang rasional dari segala sesuatu, disamping diartikan sebagai suatu sikap dan pandangan, serta suatu proses kritis dan sistematis dari segala pengetahuan manusia. Lihat Maryanto, "Refleksi dan Relevansi Pemikiran Filsafat Hukum Bagi Pengembangan IImu Hukum", J urnal Hukum, Fakultas Hukum Universitas Islam Sultan Agung Semarang, Vol. 13 (1) tahun 2003, hlm. 52-54

8 Sejatinya hakim adalah "wakil Tuhan" yang bertugas untuk menyampaikan kebenaran dan keadilan, maka setiap putusan hakim wajib mencantumkan "Demi Keadilan Berdasarkan Ketuhanan Yang Maha Esa". Adanya hakim sebagai "wakil Tuhan" dilatarbelakangi secara historis, dalam teori hukum dan negara, suara Tuhan tersebut dalam konteks renungan kefilsafatan tentang kedaulatan negara atau raja, melahirkan filsafat kedaulatan Tuhan, dan ketika dikaitkan dengan persoalan hukum dan keadilan, melahirkan filsafat renungan bahwa terminologi keadilan yang notabene ada dalam kajian filsafat dapatkah dijadikan sebagai bagian utama dalam pencapaian tujuan hukum, mengingat konsep keadilan yang bersifat abstrak sehingga diperlukan pemahaman dalam filsafat ilmu hukum yang akan menjelaskan nilai dasar hukum secara filosofis sehingga dapat membangun hukum yang sebenarnya.

Diskursus mengenai keadilan terjadi di semua belahan dunia, tidak terkecuali di Indonesia. Seperti yang diuraikan di muka, terjadinya gejolak sosial yang ada di Indonesia diduga disebabkan oleh belum terciptanya keadilan seperti yang diharapkan masyarakat Indonesia secara keseluruhan. Mengingat hal-hal yang telah diuraikan di atas, di samping itu, hadirnya keadilan semakin dibutuhkan dengan semakin meningkatnya jumlah manusia yang diiringi dengan meningkatnya kebutuhan hidup dan meningkatnya kompleksitas permasalahan yang dihadapi. Dalam rangka menjelaskan kompleksitas tersebut, maka tulisan ini dimaksudkan untuk menelaah tentang Aspek Keadilan dalam Perspektif IImu Hukum.

\section{Pembahasan}

\section{Filsafat IImu Hukum dan Tujuan Hukum}

Untuk mengetahui kerangka keseluruhan filsafat perlu diketahui terlebih dahulu apa yang dimaksud dengan filsafat itu. "Filsafat" berasal dari kata Yunani filosofie. Kata filsafat ini terdiri dari kata filo yang artinya cinta atau ingin, sedangkan sofie berarti kebijaksanaan. Filsafat artinya cinta akan kebijaksanaan, yakni kebijaksanaan hidup berarti, bahwa apa yang difikirkan dalam filsafat adalah hidup sebagai keseluruhan pengalaman dan pengertian. ${ }^{9}$ Dari beberapa cabang filsafat ilmu, pembicaraan mengenai keadilan merupakan masalah-masa-

\footnotetext{
keadilan Tuhan, M. Fauzan, "Pesan Keadilan Di Balik Teks Hukum yang Terlupakan", Varia Peradilan, Vol. XXVI ( 29) Oktober 2010, hlm. 30.

9 Dengan kata lain: objek filsafat bersifat universal, mencakup segala-galanya yang ditemui manusia. Maka dari itu memikirkan sesuatu hal secara filsafati ialah mencari arti yang sebenarnya dari hal itu dengan memandangnya dalam cakrawala yang paling luas, yakni segala yang ada.
} 
lah yang dibahas oleh filsafat ilmu hukum ${ }^{10}$, mengingat juga salah satu tujuan hukum adalah keadilan dan ini merupakan salah satu tujuan hukum yang paling banyak dibicarakan sepanjang perjalanan sejarah filsafat ilmu hukum.

Filsafat ilmu hukum, ada pula yang menyebutnya dengan istilah filsafat hukum, sesungguhnya merupakan sub dari cabang filsafat manusia, yang disebut etika atau filsafat manusia. Oleh karena filsafat ilmu hukum maupun filsafat hukum adalah ilmu yang mempelajari hukum secara filosofis maka objeknya adalah hukum. Mengenai pembedaaan ilmu hukum maupun hukum, Curzon menyebutnya bahwa ilmu hukum mencakup dan membicarakan segala hal yang berhubungan dengan hukum. Demikian luasnya masalah yang dicakup oleh ilmu ini, sehingga sempat memancing pendapat orang untuk mengatakan, bahwa "batas-batasnya tidak bisa ditentukan". ${ }^{11}$

Satjipto Rahardjo selanjutnya menambahkan, sebagaimana halnya dengan setiap cabang ilmu, maka ilmu hukum ini juga mempunyai objeknya sendiri, yaitu hukum. Seperti diuraikan sebelumnya, betapa ilmu hukum itu mencakup bidang yang luas sekali. Sifat ini merupakan akibat dari beban yang dipikulnya, yaitu memaparkan di hadapan kita fenomena hukum dalam hakikatnya, sifat-sifatnya, fungsinya dalam masyarakat sehingga oleh karena itulah bisa dimengerti, mengapa ia mengandung pikiran dan penjelasan yang cukup beragam, baik yang falsafati, teknik maupun sosiologis. ${ }^{12}$

Di dalam kepustakaan hukum, ilmu hukum ini dikenal dengan nama, jurisprudence, yang berasal dari kata jus, juris, yang artinya adalah hukum atau hak; prudensi berarti melihat ke depan atau mempunyai keahlian. Arti yang umum dari jurisprudence ini adalah ilmu yang mempelajari hukum. Tetapi orang juga mengenal tiga artinya yang lain. Para penulis Inggris memakainya dalam anatomi perban-

\footnotetext{
${ }^{10}$ Istilah Filsafat IImu Hukum dan Filsafat Hukum, ada banyak penggunaan yang bergantian menurut para pakar, Sudjito, 2010, Material Teaching Filsafat IImu Hukum, Yogyakarta: FH UGM Yogyakarta.

${ }^{11}$ Satjipto Rahardjo, 2000, IImu Hukum, Bandung: Penerbit PT. Citra Aditya Bakti, hlm. 3

12 Loc.cit
}

dingan dari sistem-sistem hukum yang sudah maju. Para penulis Prancis mengartikannya sebagai kecenderungan dari putusan yang diambil oleh pengadilan-pengadilan. Dibeberapa negara lain, terutama Amerika Serikat, kata itu dipakai sinonim dari hukum itu sendiri. ${ }^{13}$ Dari penjelasan di atas, maka jelaslah pembedaan pemakaian filsafat ilmu hukum maupun filsafat hukum terletak hanya pada tataran istilah saja, tanpa maksud memilah dan membedakannya secara pokok krusial, yang sebenarnya keduanya mempelajari filsafat yang mempunyai objek hukum.

Adapun, dilihat dari pengertiannya, filsafat IImu Hukum yang telah berkembang semenjak masa Yunani, didefinisikan oleh banyak pemikir dengan berbagai rumusan, yang pada dasarnya menyatakan bahwa filsafat ilmu hukum mempersoalkan hakikat hukum itu sendiri. Menurut Sudjito, filsafat ilmu hukum adalah institusi pencarian jawaban atas persoalan-persoalan yang dihadapi manusia, mulai dari persoalan ketuhanan, alam semesta, sampai kepada persoalan manusia itu sendiri. ${ }^{14}$

Satjipto Rahardjo mengemukakan pendapatnya bahwa filsafat hukum itu mempersoalkan pertanyaan-pertanyaan yang bersifat dasar dari hukum. Pertanyaan-pertanyaan tentang hakikat hukum, tentang dasar-dasar bagi kekuatan mengikat dari hukum, merupakan contoh-contoh pertanyaan yang mendasar itu. Gustav Radbruch merumuskannya dengan sederhana yaitu bahwa filsafat hukum itu adalah cabang filsafat yang mempelajari hukum yang benar, sedangkan Langemeyer mengatakannya pembahasan secara filosofis tentang hukum.

Rumusan lain dari Utrecht mengetengahkan sebagai berikut:

Filsafat hukum memberi jawaban atas pertanyaan-pertanyaan seperti apakah hukum itu sebenarnya (persoalan adanya dan tujuan hukum) Apakah sebabnya maka kita menaati hukum? (persoalan belakunya hukum) Apakah keadilan yang

\footnotetext{
${ }^{13} \mathrm{lbid}, \mathrm{hlm} .9$

${ }^{14}$ Loc, cit
} 
menjadi ukuran untuk baik buruknya hukum itu (persoalan keadilan hukum). ${ }^{15}$

Baik Stamler maupun Kelsen menitikberatkan keadilan sebagai tujuan hukum. Demikian pula Radbruch yaitu keadilan sebagai tujuan umum dapat diberikan arah yang berbedabeda untuk mencapai keadilan sebagai tujuan dari hukum. Oleh karena fungsi hukum adalah memelihara kepentingan umum dalam masyarakat, menjaga hak-hak manusia, dan mewujudkan keadilan dalam hidup bersama. Ketiga tujuan tersebut tidak saling bertentangan, tetapi merupakan pengisian suatu konsep dasar, yaitu manusia harus hidup dalam suatu masyarakat dan masyarakat itu harus diatur oleh pemerintah dengan baik berdasarkan hukum.

\section{Teori Keadilan menurut Plato, Aristoteles, Thomas Aquinas dan J ohn Rawls}

Masalah hubungan antara keadilan dan hukum positif jadi pusat perhatian para ahli fikir Yunani, sama halnya dengan pemikiran tentang hukum pada saat tersebut ${ }^{16}$. Di bawah ini akan diuraikan beberapa pemikiran dalam konteks keadilan dalam hukum yang penulis pilih dalam pembahasan makalah ini yaitu teori Plato, Aristoteles, Thomas Aquinas dan John Rawls. Plato dan Aristoteles dipilih mewakili dari pemikiran masa klasik yang meletakkan dasar bagi keadilan, Thomas Aquinas ${ }^{17}$ menjelaskan bertolak dari ide-ide dasar filsafat Aristoteles, sedangkan John Rawls mewakili dari pemikiran masa modern yang menegaskan de-

\footnotetext{
${ }^{15}$ Inilah pertanyaan-pertanyaan yang sebetulnya juga dijawab oleh ilmu hukum. Akan tetapi, bagi banyak orang jawaban ilmu hukum tidak memuaskan. Filsafat hukum hendak melihat hukum sebagai kaidah dalam arti kata ethisch wardeoordeel. Filsafat hukum berusaha membuat 'dunia etis yang menjadi latar belakang yang tidak dapat diraba pancaindera' dari hukum.

${ }^{16}$ W. Friedmann, op.cit, hlm 6.

17 Thomas Aquinas (1225-1275) adalah seorang rohaniwan Gerej a Katolik yang lahir di Italia, seorang doktor filsafat dan Teologi. Dalam membahas arti hukumThomas mulai membedakan antara hukum-hukum yang berasal dari wahyu dan hukum-hukum yang dijangkau oleh akal budi itu sendiri.Hukum yang didapati dari wahyu disebut 'hukum ilahi positif (ius divinum positivum). Hukum yang diketahui berdasarkan kegiatan akal budi ada beberapa macam. Pertama-tama terdapat 'hukum alam' (ius naturale), kemudian juga 'hukum bangsa-bangsa' (ius gentium), akhirnya 'hukum positif manusiawi' (ius positivum humanum).
}

ngan cara memetakan dua arus utama pemikiran keadilan di atas.

\section{Keadilan menurut Plato, Aristoteles dan Thomas Aquinas}

Persoalan keadilan menjadi hal yang utama dalam pemikiran Hukum Kodrat pada masa Yunani Kuno, dengan peletak hukum kodrat Aristoteles. ${ }^{18} \mathrm{Hal}$ ini dikarenakan pada saat itu, sudah terdapat gagasan umum tentang apa yang adil menurut kodratnya dan apa yang adil itu harus sesuai atau menurut keberlakuan hukumnya ${ }^{19}$, selanjutnya menurut Sumaryono mengemukakan

"Dalil "hidup manusia harus sesuai dengan alam" merupakan pemikiran yang di terima saat itu, dan oleh sebab itu, dalam pandangan manusia, seluruh pemikiran manusia harus didasarkan pada kodratnya tadi, sehingga manusia dapat memandang tentang hal yang 'benar' dan 'keliru'. Untuk melaksanakan peran kodrati manusia tadi, setiap manusia seharusnya mendasarkan tindakannya sesuai dengan gagasan keadilan, sehingga manusia dapat memahami dan melakukan hal-hal yang bertentangan dengan alam tempat manusia hidup". ${ }^{20}$

Merosotnya demokrasi Athena, dalam perang Peloponesus dan sesudahnya, menjadi bahan perenungan tentang keadilan yang mendominasi filsafat hukum Plato dan Aristoteles. Keduanya mencurahkan sebagian besar dari karya

\footnotetext{
${ }^{18}$ Aristoteles, murid Plato, pada dasarnya mengikuti pemikiran Plato ketika Aristoteles memulai memersoalkan tentang keadilan dan kaitannya dengan hukum positif. Namun yang membedakan diantara mereka, bahwa Plato dalam mendekati problem keadilan dengan sudut pandang yang bersumber dari inspirasi, sementara Aristoteles mendekati dengan sudut pandang yang rasional. Yang menghubungkan keduanya adalah, bahwa keduanya sama-sama berupaya membangun konsep tentang nilai keutamaan (concept of virtue), yang bertujuan untuk mengarahkan manusia kepada suatu kecondongan, yang pada dasarnya telah menjadi problem utama dalam pemikiran Hukum Kodrat masa itu, tentang arah yang baik atau arah yang buruk, berdasarkan nilai Keadilan atau tiadanya Keadilan.

${ }^{19}$ Made Subawa, "Pemikiran Filsafat Hukum Dalam Membentuk Hukum", Sarathi : Kajian Teori Dan Masalah Sosial Politik, Asosiasi IImu Politik Indonesia Denpasar, Vol. 14 (3), 2007, hlm. 244-245

20 E.Sumaryono, 2002, Etika dan Hukum: Relevansi Teori Hukum Kodrat Thomas Aquinas, Yogyakarta: Penerbit Kanisius, hlm. 92.
} 
mereka untuk memberi definisi yang konkrit mengenai keadilan dan hubungan antara keadilan dan hukum positif. Plato berusaha untuk mendapatkan konsepnya mengenai keadilan dari ilham; sementara Aristoteles mengembangkannya dari analisa ilmiah atas prinsipprinsip rasional dengan latar belakang modelmodel masyarakat politik dan undang-undang yang telah ada ${ }^{21}$.

Doktrin-doktrin Aristoteles tidak hanya meletakkan dasar-dasar bagi teori hukum, tetapi juga kepada filsafat barat pada umumnya. Kontribusi Aristoteles bagi filsafat hukum adalah formulasinya terhadap masalah keadilan, yang membedakan antara :

Keadilan "distributif" dengan keadilan "korektif" atau "remedial" yang merupakan dasar bagi semua pembahasan teoritis terhadap pokok persoalan. Keadilan distributif mengacu kepada pembagian barang dan jasa kepada setiap orang sesuai dengan kedudukannya dalam masyarakat; dan perlakuan yang sama terhadap kesederajatan di hadapan hukum (equality before the law). ${ }^{22}$

Keadilan jenis kedua pada dasarnya merupakan ukuran teknis dari prinsip-prinsip yang mengatur penerapan hukum. Dalam mengatur hubungan-hubungan hukum harus ditemukan suatu standar yang umum untuk memperbaiki setiap akibat dari setiap tindakan, tanpa memperhatikan pelakunya, dan tujuan dari perilaku-perilaku dan objek-objek tersebut harus diukur melalui suatu ukuran yang objektif.

Kontribusi ketiga dari Aristoteles adalah pembedaan antara keadilan menurut hukum dan keadilan menurut alam, atau antara hukum positif dengan hukum alam. Keadilan yang pertama mendapat kekuasaannya dari apa yang di-

\footnotetext{
21 Ibid, hlm 7.

22 Ibid, hlm. 10, dia membedakan keadilan menjadi jenis keadilan distributif dan keadilan korektif. Yang pertama berlaku dalam hukum publik, yang kedua dalam hukum perdata dan pidana. Keadilan distributif dan korektif sama-sama rentan terhadap problema kesamaan atau kesetaraan dan hanya bisa dipahami dalam kerangkanya. Dalam wilayah keadilan distributif, hal yang penting ialah bahwa imbalan yang sama rata diberikan atas pencapaian yang sama rata. Pada yang kedua, yang menjadi persoalan ialah bahwa ketidaksetaraan yang disebabkan oleh, misalnya, pelanggaran kesepakatan, dikoreksi dan dihilangkan.
}

tetapkan sebagai hukum, apakah adil atau tidak; keadilan yang kedua mendapat kekuasaannya dari apa yang menjadi sifat dasar manusia, yang tidak dibatasi oleh ruang dan waktu.

Kontribusi terbesar keempat dari Aristoteles adalah pembedaannya terhadap keadilan abstrak dan kepatutan. Hukum harus menyamaratakan dan banyak memerlukan kekerasan dalam penerapannya terhadap masalah individu. Kepatutan mengurangi dan menguj i kekerasan tersebut, dengan mempertimbangkan hak yang bersifat individual. Semua pembahasan masalah mengenai kepatutan, ketepatan interpretasi terhadap undang-undang atau preseden, bermula dari pernyataan terhadap masalah yang fundamental.

Thomas Aquinas, yang dikenal sebagai penerus tradisi filsafat ala Aristoteles, sampai tingkat tertentu meneruskan garis pemikiran Aristoteles dan juga kaum Stoa ${ }^{23}$. Thomas membedakan 3 (tiga) macam hukum yaitu hukum abadi (lex actena), hukum kodrat (lex naturalis), dan hukum manusia dan hukum positif (lex humana) ${ }^{24}$ serta memberikan pandangannya mengenai masalah keadilan itu. Keutamaan yang disebut keadilan menurut Thomas Aquinas menentukan bagaimana hubungan orang dengan orang yang selain dalam hal iustum, yakni mengenai apa yang sepatutnya bagi orang lain menurut sesuatu kesamaan proporsional (aliquod opus adaequatum alteri secundum aliquem aequalitatis modum).

\footnotetext{
${ }^{23}$ Menurut Kaum Stoa: manusia adalah makhluk rasional yang diciptakan Tuhan sesuai dengan hakikatnya dan akal budi terdapat pada manusia, maka hal pertama yang dimiliki secara barusan oleh manusia dan Tuhan adalah akal budi.

${ }^{24}$ Hukum abadi adalah kebijakan atau rencana abadi Tuhan berkaitan dengan pencarian alam semesta atau dunia dengan segala isinya. Hukum kodrat adalah perwujudan kebijaksanaan atau rencana abadi tadi dalam kodrat manusia. Hukum manusia adalah ketentuan tertentu dari akal budi manusia demi kepentingan bersama yang dibuat oleh orang yang peduli terhadap komunitas dan diberlakukan secara merata bagi semua orang. Selanjutnya hukum ini harus memenuhi syarat formal dan material tertentu. Secara formal hukum manusia harus adil dan dimaksudkan untuk kesejahteraan manusia. Secara materiil : pertama, hukum manusia sah kalau begitu saja mengungkapkan hukum kodrat; kedua, hukum manusia sah kalau merupakan kesimpulan logis dari hukum kodrat; ketiga, hukum manusia sah kalau memberi keterangan dalam hal yang memang harus di atur, tetapi dari segi hukum kodrat masih tetap terbuka kepada pengaturan mana yang mau dipilih
} 


\section{Keadilan menurut J ohn Rawls}

Pada Abad Modern salah seorang yang di anggap memiliki peran penting dalam mengembangkan konsep keadilan adalah John Borden Rawls. Rawls, berpendapat bahwa keadilan hanya dapat ditegakkan apabila negara melaksanakan asas keadilan, berupa setiap orang hendaknya memiliki hak yang sama untuk mendapatkan kebebasan dasar (basic liberties); dan perbedaan sosial dan ekonomi hendaknya distur sedemikian rupa sehingga memberi manfaat yang besar bagi mereka yang berkedudukan paling tidak beruntung, dan bertalian dengan jabatan serta kedudukan yang terbuka bagi semua orang berdasarkan persamaan kesempatan yang layak.

J ohn Rawls memunculkan suatu ide daIam bukunya A Theory of J ustice atau teori keadilan yang bertujuan agar dapat menjadi alternatif bagi doktrin-doktrin yang mendominasi tradisi filsafat terdahulunya, dengan cara menyajikan konsep keadilan yang mengeneralisasikan dan mengangkat teori kontrak sosial yang diungkap oleh, katakanlah, Locke, Rousseau dan Kant ke tingkat yang lebih tinggi. Oleh Rawls cara pandang keadilan ini disebut keadilan sebagai fairness.

Keadilan sebagai fairness dimulai dengan salah satu pilihan yang paling umum yang bisa dibuat orang bersama-sama, yakni dengan pilihan prinsip pertama dari konsepsi keadilan yang mengatur kritik lebih lanjut serta reformasi institusi. Teori Rawls didasarkan atas dua prinsi ${ }^{25}$ yaitu melihat tentang Equal Right dan Economic Equality. Dalam Equal Right dikatakannya

"Harus diatur dalam tataran leksikal, yaitu different principles bekerja jika prinsip pertama bekerja atau dengan kata lain prinsip perbedaan akan bekerja jika basic right tidak ada yang dicabut (tidak ada pelanggaran HAM) dan meningkatkan ekspektasi mereka yang kurang beruntung. Dalam prinsip Rawls ini ditekankan harus ada pemenuhan hak dasar sehingga

\footnotetext{
${ }^{25}$ Wibowo, "Teori Keadilan J ohn Rawls", tersedia di website http:// www. file://localhost/ D:/ Filsafat Manusia, diakses tanggal 29 Oktober 2010.
}

prinsip ketidaksetaraan dapat dijalankan dengan kata lain ketidaksetaraan secara ekonomi akan valid jika tidak merampas hak dasar manusia."

Bagaimanapun, definisi Aristoteles jelasjelas mengasumsikan penilaian tentang apa yang layak menjadi milik seseorang dan apa yang berkaitan dengannya. Sekarang kekuasaan semacam itu, kerap kali diturunkan dari institusi-institusi sosial dan ekspetasi yang salah. Tidak ada alasan untuk berpikir bahwa Aristoteles tidak akan setuju dengan hal ini, ia tentu punya konsep keadilan sosial untuk menilai klaim-klaim tersebut. Definisi yang Rawls ajukan secara langsung dirancang untuk kasus yang paling penting, yakni keadilan struktur dasar. Tidak ada konflik dengan pandangan tradisional ${ }^{26}$.

\section{Keadilan dalam Perspektif Filsafat IImu Hu- kum}

Hubungan antara keadilan dan hukum positif baru mulai abad 8 yang dilatarbelakangi oleh adanya kekacauan dalam masyarakat, tidak puasnya rakyat dengan pemerintahan aristokrasi dan penyalahgunaan dari kekuasaan ${ }^{27}$. Sejak waktu itu maka masalah hubungan antara keadilan dan hukum positif menguasai alam pikiran bangsa Yunani, dan pada hakekatnya semua pikiran-pikiran tentang hukum. Dalam hubungannya dengan filsafat ilmu hukum, keadilan diwujudkan melalui hukum sehingga dapat disimpulkan bahwa hukum yang mewujudkan keadilan itu mutlak perlu dalam kehidupan bersama manusia. Tanpa hukum kehidupan manusia menjadi kacau dan akan kehilangan kemungkinan untuk berkembang secara manusiawi. ${ }^{28}$

\footnotetext{
${ }^{26} \mathrm{lbid}, \mathrm{hlm} .11-12$.

${ }^{27}$ Masalah keadilan menguasai syair-syair Hesiod dan Solon, pembuat undang-undang Atica yang tersohor. Keduaduanya minta pertolongan dari Dike putrid Zeus sebagai penjamin keadilan terhadap tirani dunia, pelang-garan hak-hak dan tidak adanya keadilan sosial. Solon menggambarkan Dike, sebagai seorang dewi yang menghukum kekacauan dan tidak keadilan dengan"kejahatankejahatan sosial" (social evil) sedang masyarakat yang adil dianugrahi dengan perdamaian dan kemakmuran.

28 Sewu, P. Lindawaty S, "Kegunaan Filsafat Hukum Dalam Mengupas Tuntas Permasalahan Hukum Kontekstual",
} 
Friedmann ${ }^{29}$ mengatakan, para ahli fikir Romawi telah meletakkan dasar-dasar ilmu hukum analisis modern, sekalipun sumbangan mereka terhadap filsafat hukum tidak banyak. Dari mulai Cicero sampai Plato dan Aristoteles, mulai dari tulisan mengenai hukum kontrak ataupun menuju pada pemikiran-pemikiran yang mendalam tentang fungsi dan problemaproblema hukum di dalam masyarakat. Kekacauan-kekacauan sosial, konflik-konflik intern, sering terjadinya pergantian pemerintahan, banyaknya kezaliman dan kesewenang-wenangan, merupakan dorongan ektern untuk merenungkan hubungan antara keadilan tertinggi dengan hukum positif.

Dikatakan dalam karya Homerus ${ }^{30}$ bahwa hukum merupakan pusat kajian dan merupakan sesuatu yang pasti dan tetap. Keadilan masih identik dengan perintah dan kewenangan. Kesadaran akan adanya pertentangan antara hukum positif dan keadilan menjadi lebih menonjol sejak abad kedelapan. Keadaan itu timbul karena adanya rasa tidak aman dalam masyarakat, rasa tidak puas terhadap sistem pemerintahan aristokrasi dan banyaknya penyalahgunaan kekuasaan. Pada masa itu memang pertentangan antara keadilan versus ketidakadilan terjadi. Adanya hal-hal tersebut di atas menjadi pusat perhatian para ahli fikir Yunani, sama halnya dengan pemikiran tentang hukum sejak saat tersebut bahkan sampai sekarang.

Susanto mencoba menganalisis apabila mencoba memfokuskan pada kajian-kajian pada pandangan-pandangan di atas maka keadilan tidak dapat ditemukan di luar sebuah tatanan yang tertib dan teratur, entah tatanan hukum, tatanan moral atau tatanan itu adalah tatanan rasio dan keadilan eksis di dalam tatanan ter-

Wacana Paramarta: J urnal IImu Hukum, Fakultas Hukum Universitas Langlangbuana, Vol. 5 (1), 2006, hlm. 25-38

${ }^{29}$ W. Friedmann, op.cit, hlm.5.

${ }^{30}$ Karya-karya Homerus adalah hasil pertama peradaban Hellenis yang menonjol. Segala hal mengenai Homerus sebetulnya bersifat dugaan, namun opini yang terkuat menunjukkan bahwa Homerus sesungguhnya adalah sejumlah penyair dan bukan hanya satu orang. Penulis modern dalam ilmu antropologi sampai pada kesimpulan bahwa Homerus adalah seorang juru sensor yang samasekali jauh dari ciri primitive, sejenis ahli tafsir abad ke-18 yang merasionalisir mitos-mitos kuno, yang menjunjung cita-cita kelas atas untuk mencapai peradaban tinggi. sebut. Maka dengan melihat pada pendapat Hans Kelsen yang mewakili kaum Positivisme Hukum, bahwa makna keadilan adalah keadilan yang diberlakukan dan jika ditelusuri lebih jauh terlihat bahwa pencarian keadilan diluar tatanan adalah (seolah) tidak mungkin, artinya pencarian keadilan di luar tatanan telah dihentikan. ${ }^{31}$

Tugas filsafat hukum adalah memformulir cita-cita politik dalam istilah-istilah keadilan dan ketertiban hukum. Sebagaimana dikatakan oleh Radbruch :

"Alle grossen politischen Wandlungen waren vor der Rechtspholosophie vorbereitet oder begleitet. Am anfang stand die Rechtsphilosophie, am Ende die Revolution". All great political changes were prepared or accompanied by legal philosophy. In the beginning there was legal philosophy; at the end, there was revolution". ${ }^{32}$

Melihat dari uraian mengenai terminologi keadilan di atas jelaslah bahwa untuk dapat melihat adanya gambaran keadilan terdapat ukuran tersendiri yang dapat mengukurnya. Bersandar pada gambaran itulah maka penulis mengambil kesimpulan bahwa keadilan dalam hukum terbagi pada 2 (dua) hal yakni keadilan menurut perundang-undangan (legal justice) atau keadilan dalam praktek (practical justice). Keadilan berdasarkan perundang-undangan didasarkan pada hukum yang tertulis dan ada dalam teks perundang-undangan.

Memaknai keadilan memang selalu berawal dari keadilan sebagaimana juga tujuan hukum yang lain yaitu kepastian hukum dan kemanfaatan. Keadilan memang tidak secara tersurat tertulis dalam teks tersebut tetapi pembuat undang-undang telah memandang dalam pembuatan produk perundang-undangannya didasarkan pada keadilan yang merupakan bagian dari tujuan hukum itu sendiri, seperti ada dalam teori etis bahwa tujuan hukum semata-mata untuk mewujudkan keadilan (justice), yang dimuat dalam teori tujuan hukum klasik sedangkan dalam teori prioritas modern

\footnotetext{
${ }^{31}$ Anthon F. Susanto, loc. cit, hlm. 33

$32 \mathrm{lbid}, \mathrm{hlm} .24$.
} 
baku yang ada dalam teori modern yaitu tujuan hukum mencakupi keadilan, kemanfaatan dan kepastian hukum.

Berkenaan dengan adanya tujuan hukum tersebut, di samping keadilan menjadi salah satu dari dibuatnya teks hukum maka tujuan hukum pun menjadi dasar yang menjadi acuan bagi seorang hakim dalam menetapkan putusannya. Hakim secara formal meletakkan dasar pertimbangan hukumnya berdasarkan teks undang-undang (legal formal) dan keadilan menjadi harapan dari putusan tersebut. Akan tetapi kemudian yang terjadi adalah makna keadilan ini menjadi sempit manakala salah satu pihak menganggap bahwa putusan hakim itu menjadi tidak adil baginya dan hal ini yang kemudian membawa pada pemikiran bahwa selalu terjadi disparitas antara keadilan dan ketidakadilan. Bahwa memang makna keadilan itu bisa jadi menjadi tidak sama atau dengan kata lain mempunyai perspektif yang berbeda.

Aristoteles membagi keadilan menjadi tiga macam. Adanya pembedaan keadilan menjadi tiga apabila dilihat dari keterangan mengenai definsi masing-masing dan ketiganya jelas berbeda. Keadilan yang dimaksud disini adalah keadilan dalam pengertian kesamaan. Keadilan jenis ini kemudian membedakan pada jenis pembagian keadilan distributive, dan corrective atau remedial justice. Keadilan seperti diuraikan dalam pembagian tersebut, sejatinya dilaksanakan dalam kenyataan tapi keadilan masyarakat (dalam pembagian di atas tadi, selain keadilan berdasarkan teks undangundang) merupakan keadilan yang merupakan harapan masyarakat. Ketentuan Pasal 16 Ayat (1) UU No. 4 Tahun 2004 pun memperkuat keadilan jenis ini, yang menyatakan bahwa keadilan menjadi wajib untuk tetap ditegakkan kendati pun tidak ada ketentuan hukum normatif. Keadilan merupakan kebutuhan pokok rohaniah dalam tata hubungan masyarakat, keadilan merupakan bagian dari struktur rohaniah suatu masyarakat. Suatu masyarakat memiliki gambaran tentang mana yang patut dan tidak patut, mana yang benar dan yang salah, kendati pun dalam masyarakat tersebut tidak ada undang-undang tertulisnya. Di sisi yang lain, dalam pasal 5 ayat (1) UU No.48 Tahun 2009 tugas hakim yaitu menggali dan memahami nilai-nilai hukum dan rasa keadilan yang hidup dalam masyarakat.

Berbicara dalam konteks filsafat ilmu hukum, dalam semua aliran manapun, cara berfikir apa pun yang dipakai, semua pemikiran tentang hukum secara sistematis (berfilsafat tentang hukum), berlandaskan di satu pihak pada filsafat (pandangan manusia tentang tempatnya di alam semesta) dan di lain pihak pada teori politik (pandangan manusia tentang bentuk masyarakat yang terbaik). Pikiran tentang tujuan hukum berdasar pada "konsepsi" (pandangan) manusia sebagai manusia yang berfikir (thinking individual) dan sebagai makhluk berpolitik (political being). Dua aspek ini yang harus diperhatikan dalam menjawab pertanyaan tentang filsafat ilmu hukum.

Memperhatikan semua pembahasan dalam tulisan ini, bahwa keadilan dalam filsafat ilmu hukum itu tetap akan ada sepanjang usia pelaksanaan penegakan hukum dan akan dipegang teguh karena keadilan merupakan cita dan mengimbangi unsur lainnya yaitu keman-faatan dan kepastian hukum. Pemahaman akan filsafat ilmu hukum benar akan dapat men-jelaskan nilai dasar hukum secara filosofis dan sudah seharusnya semakin diperkuat oleh para para pihak yang kompeten sehingga dapat membangun hukum yang sebenarnya.

\section{Penutup}

\section{Simpulan}

Filsafat IImu Hukum memberikan perspektif bahwa keadilan diwujudkan dalam hukum. Masalah hubungan antara keadilan dan hukum positif dibahas menurut Plato dan Aristoteles yang meletakkan dasar bagi keadilan. Ide Plato berupa keadilan ilham, Aristoteles yang membedakan tiga jenis keadilan distributif, korektif dan remedial. Thomas Aquinas yang bertolak dari ide-ide dasar Aristoteles menyebut keadilan sebagai suatu kesamaan proporsional sedangkan J ohn Rawls, yang memetakan dua pendapat peletak keadilan di atas dan cara pandang keadilan disebutnya keadilan 
sebagai fairness dengan didasarkan 2 (dua) prinsip yaitu equal right dan economic quality.

Secara normatif, pelaksanaan keadilan di masyarakat bersandarkan pada ketentuan Pasal 16 Ayat (1) UU Nomor 4 tahun 2004 yang menyatakan bahwa keadilan menjadi wajib untuk tetap ditegakkan kendatipun tidak ada ketentuan normatif. Dalam tataran praktikal, hakim berdasarkan Pasal 5 Ayat (1) UU Nomor 48 tahun 2009 mempunyai tugas menggali dan memahami nilai-nilai hukum dan rasa keadilan dalam masyarakat.

\section{Daftar Pustaka}

Amin, M. Kebenaran Hukum Vs Keadilan Masyarakat. Website http:// www. Palubukpakam. net/ artikel/ 186-kebenaran hukum -vs-keadilan-masyarakat.html, diakses 9 Oktober 2010;

Fauzan, M. "Pesan Keadilan Di Balik Teks Hukum yang Terlupakan". Varia Peradilan, Vol. XXVI No. 29 Oktober 2010;

Friedmann. W.1990. Teori dan Filsafat Hukum, J akarta: PT. Rajawali Press;

Husni, M. "Moral dan Keadilan sebagai Landasan Penegakan Hukum Yang Responsif". Jurnal Equality Vol. 11 No. 1 Februari 2006. Fakultas Hukum Universitas Sumatera Utara;

Indarti, Erlyn. "Demokrasi dan Kekerasan: Sebuah Tinjauan Filsafat Hukum". Jurnal Aequitas Juris, Vol. 2 (1), 2008. Fakultas Hukum Universitas Katolik Widya Mandira Kupang;
J ulia, Syamsiar. "Pelanggaran HAM Dan Peranan Polri Dalam Penegakan Hukum di Indonesia". Jurnal Equality Vol. 11 No. 2 Agustus 2006. Fakultas Hukum Universitas Sumatera Utara;

Lubis, Todung Mulya. "Menegakan Hak Asasi Manusia, Menggugat Diskriminasi". J urnal Hukum dan Pembangunan Vol. 39 (1) Januari-Maret 2009. FH UI J akarta;

Maryanto. "Refleksi dan Relevansi Pemikiran Filsafat Hukum Bagi Pengembangan IImu Hukum". J urnal Hukum, Vol. 13 (1) 2003. FH Unisulla Semarang,

Muchsan. 1985. Hukum Tata Pemerintahan, Yogyakarta: Penerbit Liberty

Rahardjo, Satjipto. 2000. Ilmu Hukum. Bandung: PT. Citra Aditya Bakti;

Sewu, P. Lindawaty. "Kegunaan Filsafat Hukum Dalam Mengupas Tuntas Permasalahan Hukum Kontekstual", Wacana Paramarta: J urnal IImu Hukum, Vol. 5 (1), 2006. FH Universitas Langlangbuana;

Subawa, Made. "Pemikiran Filsafat Hukum daIam Membentuk Hukum". J urnal Sarathi: Kajian Teori Dan Masalah Sosial Politik, Vol. 14 (3), 2007. Asosiasi IImu Politik Indonesia Denpasar;

Sudjito. 2010. Material Teaching Filsafat IImu Hukum. Yogyakarta: FH UGM;

Sumaryono, E. 2002. Etika dan Hukum: Relevansi Teori Hukum Kodrat Thomas Aquinas. Yogyakarta: Penerbit Kanisius;

Susanto, Anthon F. "Keraguan dan Ketidakadilan Hukum (Sebuah Pembacaan Dekonstruktif)". Jurnal Keadilan Sosial, Edisi 1 tahun 2010. 